\title{
EXISTENCE OF SOLUTIONS TO NONLINEAR STURM-LIOUVILLE PROBLEMS WITH LARGE NONLINEARITIES
}

\author{
BENJAMIN FREEDMAN* AND JESÚs RODRÍGUEZ
}

\begin{abstract}
In this paper, we present results which allow us to establish the existence of solutions to nonlinear Sturm-Liouville problems with unbounded nonlinearities. We consider both regular and singular problems. Our main results rely on a variant of the Lyapunov-Schmidt used in conjunction with topological degree theory.
\end{abstract}

Mathematics subject classification (2010): 34A34, 34B15, 47H11.

Keywords and phrases: Boundary value problems, ordinary differential equations, nonlinear equations.

\section{REFERENCES}

[1] P. Canuto, M. Y. Hussaini, A. Quateroni, T. A. Zang, Spectral Methods in Fluid Dynamics, Springer-Verlag, Berlin Heidelberg 1988.

[2] S. Chow, J. K. Hale, Methods of Bifurcation Theory, Spring, Berlin, 1982.

[3] L. CESARI, Functional analysis and periodic solutions of nonlinear differential equations, Contributions to differential equations, 1, (1963), 149-187.

[4] L. CESARI, Functional analysis and Galerkin's method, The Michigan Mathematical Journal, 11, 4 (1964), 385-414.

[5] E. Coddington, J. Levinson, Theory of Ordinary Differential Equations, McGraw-Hill, 1955.

[6] P. DRABEK, Landesman-Lazer type condition and nonlinearities with linear growth, Czechoslovak Math Journal 40, (1990), 70-86.

[7] P. DRABEK, On the resonance problem with nonlinearity which has arbitrary linear growth, Journal of Mathematical Analysis and Application 127, (1987), 435-442.

[8] D. L. Etheridge, J. Rodríguez, Scalar discrete nonlinear two-point boundary value problems, Journal of Difference Equations and Applications, 4, 2 (1998), 127-144.

[9] L. Ferreira, L. SANChez, On a class of difference equations involving a linear map with two dimensional kernel, 8 (2020), 1-14.

[10] G. Folland, Fourier analysis and its applications, American Mathematical Society, 2009.

[11] B. FreEdman, J. RodRíGUeZ, Existence of solutions to nonlinear Legendre boundary value problems, Differential Equations and Applications 11, 4 (2019), 495-508.

[12] B. Freedman, J. Rodríguez, On Nonlinear Boundary Value Problems in the Discrete Setting, Journal of Difference Equations and Applications, 25, 7 (2019), 994-1006.

[13] J. HALE, Ordinary differential equations, New York, 1980.

[14] W. G. Kelley, A. C. Peterson, The Theory of Differential Equations, Springer, 2010.

[15] R. MA, Existence of Positive Solutions for Second-Order Boundary Value Problems on Infinity Intervals, Applied Mathematics Letters 16, (2003), 33-39.

[16] R. MA, Nonlinear discrete Sturm-Liouville problems at resonance, Nonlinear Analysis 67, (2007), 3050-3057.

[17] D. MaroncelLi, Scalar multi-point boundary value problems at resonance, Differential Equations and Applications 7, 4 (2015), 449-468.

[18] D. MARONCELLI, Nonlinear scalar multipoint boundary value problems at resonance, Journal of Difference Equations and Applications 24, 12 (2018), 1935-1952.

[19] D. Maroncelli, J. RodríGUez, Periodic behaviour of nonlinear, second-order discrete dynamical systems, Journal of Difference Equations and Applications 22, 2 (2016), 280-294. 
[20] D. Maroncelli, J. RodríGuez, On the solvability of nonlinear discrete Sturm-Liouville problems at resonance, International Journal of Difference Equations 12, 1 (2017), 119-129.

[21] D. MARONCElLI, J. RodRíGUEZ, Existence theory for nonlinear Sturm-Liouville problems with nonlocal boundary conditions, Differential Equations and Applications 10, 2 (2018), 147-161.

[22] D. MARONCElli, J. RodríGUeZ, Existence theory for nonlinear Sturm-Liouville problems with unbounded nonlinearities, Journal of Difference Equations and Applications 6, 4 (2014), 455-466.

[23] J. Rodríguez, Nonlinear discrete Sturm-Liouville problems, J. Math Anal. Appl., 308, 1 (2005) $380-391$.

[24] J. RODRÍGUEZ, An alternative method for boundary vallue problems with large nolinearities, Journal of Differential Equations, 43, (1982) 157-167.

[25] J. Rodríguez, Z. Abernathy, On the Solvability of Nonlinear Sturm-Liouville Problems, Journal of Mathematical Analysis and Applications, 387, 1 (2012), 310-319.

[26] J. Rodríguez, Z. Abernathy, Nonlinear discrete Sturm-Liouville problems with global boundary conditions, Journal of Difference Equations and Applications 18, 1 (2012), 431-445.

[27] J. RodrígueZ, A. J. SuAREZ, On nonlinear perturbations of Sturm-Liouville problems in discrete and continuous settings, Differential Equations and Applications 8, 3 (2016), 319-334.

[28] J. RodríGUEZ, P. TAYLOR, Scalar discrete nonlinear multipoint boundary value problems, Journal of Mathematical Analysis and Applications 330, 2 (2007), 876-890.

[29] J. F. RodríGUEZ, Existence theory for nonlinear eigenvalue problems, Applicable Analysis, 87 (2008) 293-301.

[30] N. Rouche, J. Mawhin, Ordinary differential equations: Stability and periodic solutions, Pittman Advanced Pub. Program, 1980. 